the bequest so that our collections become the final repository for this great memorial canvas.

Upon his last visit to the Historical Department General Dodge was shown the apartment in which we proposed to assemble his materials as a Grenville M. Dodge memorial. The architectural features were discussed and their preparation left with the approval of General Dodge to his friend, the eminent architect, Emanuel L. Masqueray. The proposed method of treating the vast manuscript collections and the publication features were broadly canvassed. Soon after the death of General Dodge our Board of Trustees approved the plan of the Curator for the memorial room and the policy of publication, and appointed as a committee thereon Judge Horace E. Deemer and the Curator.

The death of General Dodge occurred on January 3, 1916, that of Judge Deemer on February 26, 1917, and of Mr. Masqueray on May 26, 1917. The general outlines for both the structural and literary features of the memorial were rapidly taking shape when the loss of these two advisers came. But when the whole country turned its attention to the war our own department awaited more settled conditions to take up and complete its work on the memorial of General Dodge. Recently we have received the final portions of the great collection. More than a million items of written and printed matter not only bearing upon, but indispensable to the understanding of western industrial, political and military subjects of greatest importance are now assembled. Plans for their final repository and use will be ready to be announced in the Ansals in an early issue, and their completion will, we believe, be in full compliance with the letter and spirit of the great bequest of General Dodge.

\title{
BLACKSTONE ON PRESERVING HISTORICAL MATERIALS
}

Sir William Blackstone, in Vol. II of "Law Tracts." published at "Oxford, at the Clarendon Press, M. DCC. LXII." nresenting "the Great Charter and Charter of the Forest, with other Authentic Instruments: to which is prefixed An Introductory Discourse, containing The History of the Charters," explains how 
the original parchment manuscript of the charters happened to remain in existence in his time. His works are no more pertinent to the history and the principles of English common law than are these words commendatory of the traits of such as Charles Aldrich, which resulted in the founding and promotion of Iowa historical collections in our own institution. Blackstone says :

New as this account may appear and unnoticed by all our hiftorians, except very imperfectly by Tyrrel, it is however inconteftably confirmed by the original charter itfelf now preferved in the Bodleian library at Oxford; from which the following copy is very carefully and exactly printed. This charter is in breadth feventeen inches, and in length (including the fold for the label) twenty three. It has the following endorfement on it in a cotemporary hand, Magna Carta Caps. xiiij de Lanc. te. which feems to have been a mark denoting the capfule or drawer, wherein it was depofited at the abbey of Gloucefter, to which religious houfe it is thought to have once belonged. In a fomewhat later but very antient hand it is alfo thus endorfed, Carta $H$. regis de libertatibus magne carte $H$. reg. avi noftri. Regiftratur $W$. . . . . at. There ftill remain affixed to it by parchment labels the feals of Gualo the legate and William Marefcall earl of Pembroke, the former in white wax, the latter in green; both which are exhibited with their feveral imperfections in the plate, page 71 .

This invaluable piece of antiquity was bequeathed (among others) to the univerfity of Oxford by the late reverend Richard Furney, M. A. archdeacon of Surry. And it were much to be wifhed that all gentlemen, who are poffeffed of fimilar curiofities, would follow fo laudable an example, by placing them in fome public repofitary. The collecting and hoarding of antiquities, which, when confined to private amufement and felf-fatisfaction only, are too juftly the object of ridi- 
cule, would then be of fingular advantage to the public. However, we may congratulate the prefent age on the profpect there is of feeing the paths to thefe hidden treafures made fufficiently eafy and commodious, not only by the immenfe fund of antient learning which the wifdom of the legiflature has amaffed together and depofited in the Britifh Mufeum; but alfo by a plan which has long employed the attention of the noble and honourable truftees of the Radcliffe library in Oxford, for transferring to that auguft edifice all the MSS which are at prefent the property of the univerfity, and appropriating it for the future to the reception of MSS only: a defign, which will exhibit in one view, and preferve with the utmoft fecurity, that ineftimable treafure which now lies inconveniently difperfed; will give room for the daily acceffions of printed books to the Bodleian library; will perpetuate, by a proper arrangement, the memory of former benefactors to letters, and be the means of exciting new ones; and will in the end do the higheft honour to the name of the munificent founder, by ftamping a peculiar and moft ufeful character of its own on that noble ftructure, which it ever muft want if confidered only as a fupplement to former libraries. How far this plan will be adopted, is not hitherto fully determined; yet it cannot but feem an aufpicious omen, that the ample firft-fruits of doctor Radcliffe's endowment have been lately applied with the utmoft propriety to the purchafe of M. Frafer's very curious and numerous collection of oriental MSS. 
Copyright of Annals of Iowa is the property of State of Iowa, by \& through the State Historical Society of Iowa and its content may not be copied or emailed to multiple sites or posted to a listserv without the copyright holder's express written permission. However, users may print, download, or email articles for individual use. 